\title{
Serum Iron, Serum Ferritin and Hepatic Iron Content as a Predictive Values for Combined Therapy of Chronic Hepatitis C Patients
}

\author{
El-Kholy NM*, Saleh BM ${ }^{* *}$, Ragab SH ${ }^{* * *}$, Khalil AM$^{* * * *}$, \\ El-Shazly SH*, El-Hosary YA* \\ *Tropical Medicine, Faculty of Medicine for Girls Al Azhar University, \\ **Medicine Liver Institute, Menofeya University, ***Clinical Pathology National \\ Research Center, ****Pathology Department Cairo University.
}

\begin{abstract}
This Study was carried out on 40 patients with chronic hepatitis $\mathrm{C}$ virus who were selected with special inclusion criteria. All cases were subjected to evaluation by liver function tests (especially transaminases), HCV RNA (by PCR quantitative method), serum iron and serum ferritin. Liver biopsy was taken for histopathological study and detection of iron content. According to hepatic iron staining in liver biopsies of the 40 patients, the patients were classified into 4 groups ( 0 , I, II, III hepatic iron grade) (20, $10,8,2$ cases) respectively. All the patients were subjected to combined therapy (ribavirin and interferon alpha $2 \mathrm{~b}$ ) for $6 \mathrm{~ms}$. then the patients were evaluated for the biochemical response (AST, ALT) virological response (HCV RNA viraemia) and histopathological response. Also serum iron, Serum ferritin and hepatic changes were estimated.

This study revealed that there was a statistical significant difference in hepatic iron grade 0, I and II with no statistical significant difference in grade III hepatic iron as regards AST and ALT before and after the therapy. Also there was statistical significant difference in serum ferritin before and after therapy only in grade 0 and I hepatic iron although there was no significant difference found as regard serum iron level changes in all grades of hepatic iron before and after therapy.

For the virological response there was a statistical significant difference as regards undetectable viraemia after therapy in total patients $(30 \%)$ and in patients with hepatic iron grade $0(45 \%)$ while no significant difference found in patients with grade I hepatic iron $(30 \%)$, although no patients were found to have undetectable viraemia after therapy in grade II and III hepatic iron.

For the histopathological response there was a statistical significant improvement of necroinflammatory activity score in hepatic iron grades 0 , I and II while no significant improvement found in hepatic iron grade III after the course of the treatment compared to baseline biopsies (before the treatment)

Also for the changes of fibrosis stages after therapy, there was no significant improvement in total cases and in patients with different hepatic iron grades.

Out of 20 patients with hepatic iron staining (grades I, II, III) before therapy, only in 4 cases improved the hepatic iron staining after therapy with no statistical significant change.
\end{abstract}




\section{Introduction}

Chronic hepatitis $\mathrm{C}$ virus infection is a major cause of chronic liver disease with increasing mortality throughout the world. Egypt has higher rates of $\mathrm{HCV}$ infection (18.1\% of the Egyptians) than other countries (W.H.O. 1999). Degree of hepatitis $\mathrm{C}$ viraemia (HCV RNA) is one of the most predictive factors for the outcome of therapy (Chayama et al., 2001).

Liver biopsy is a very important indicator for necroinflammatory activity and fibrosis which are two major histological features of chronic hepatitis $\mathrm{C}$, and which provides useful inform ation for selection of patients with hep atitis $\mathrm{C}$ for interferon therapy (Kaserer et al., 1998).

Hepatic iron content is related to biochemical and histological markers of liver inflammation in patients with hepatitis C. Also those patients have evidence of enhanced hepatic iron accumulation. Fabris et al. (2001) said that the serum iron and ferritin are believed to be elevated in patients with hepatitis $\mathrm{C}$ virus infection in connection to the presence of hepatic inflammation. Also they stated that the serum iron reflects the degree of current hepatic inflammation and necrosis, where as the extent of progressive deposition of hepatic iron in sites of fibrosis is best reflected by serum ferritin.

The combination of interferon alfa $2 b$ and ribavirin is one of the main lines of treatment for chronic hepatitis $\mathrm{C}$. There is significant improvement in activity grades and fibrosis progression rates when biopsies performed 24 weeks after the end of the treatment compared with the baseline biopsies (Poynard et al., 1998) also to test HCVRNA at this time (Schalm et al., 1997).

\section{Aim of the work}

This study aimed to detect the relation between serum iron, serum ferritin and hepatic iron content with the response to interferon alfa-2b and ribavirin combined therapy in patients with chronic hepatitis $C$ virus infection.

\section{Subjects and Methods}

Forty patients were selected from the patients attending Tropical Medicine Department of Al Zahraa hospital, Al Azhar University and from Hepatology Department of National Liver Institute, Menofeya University. The selected cases were already diagnosed as having chronic hepatitis $C$ (with no evidence of cirrhosis) and fulfilling the following criteria (inclusion criteria):

Positive HCV antibody by ELISA second generation, negative hepatitis $\mathrm{B}$ surface antigen ( $\mathrm{Hbs} \mathrm{Ag}$ ), persistent elevation of serum ALT and AST (nearly twice normal) for 6 months prior to entry to the study while normal other Liver function tests e.g. (serum bilirubinalkaline phosphatase) normal prothrombine tIme and concentration. Also never treated by interferon or ribavirin before and negative for active schistosomiasis by urine and by sigmoidoscopy as well as rectal snip examination. As regards the blood picture, haemoglobin level not less than $10 \mathrm{gm} / \mathrm{dl}$, red blood cell count not less than 3 millions $/ \mathrm{mm}^{3}$, white blood cell count not less than $3000 / \mathrm{mm}^{3}$ and platelet count not less than $15,000 / \mathrm{mm}^{3}$. All patients had normal kidney function tests. On the other hand, the selected female patients must not be pregnant before or during the therapy, and not receiving contraceptive pills.

The selected cases were treated with recombinant interferon alpha-2b at a dose of 3 million units subcutaneous injections, 3 times weekly plus ribavirin at a dose of 1200 gm every day (2 capsules 3 times daily) for 6 months.

All the cases were subjected to the following: before treatment complete 
history taking, full clinical examination, laboratory investigation (liver function tests, prothrombin concentration, complete blood picture, serum iron and serum ferritin levels), quantitative $\mathrm{HCV}$ RNA (by quantitative PCR technique), abdominal ultrasonography. Liver biopsy was taken for histopathological study (Knodell et al., 1981) and detection of iron content (Rowe et al., 1977) by formalin-fixed paraffinembedded sections of liver tissue which was stained by hematoxlin and eosin and with Prussian blue stain for trivalent iron.

Monthly follow up of cases during therapy, and evaluation of patients after 6 months therapy for any recent complaint were done. Laboratory investigations (as before the treatment), and liver biopsy for histological study and detection of hepatic iron content changes after the treatment were done.

Table I: Levels of HCV RNA viraemia (Roche Molecular Systems)

\begin{tabular}{ll}
\hline HCV RNA count/lU ml & Levels \\
\hline Less than $600 \mathrm{IU} / \mathrm{ml}$ & Undetectable \\
$600-250,000 \mathrm{IU} / \mathrm{ml}$ & Low viraemia \\
$250,000-2,500,000 \mathrm{IU} / \mathrm{ml}$ & Moderate viraemia \\
$2,500,000-5,000,000 \mathrm{IU} / \mathrm{ml}$ & High viraemia \\
More than $5,000,000 \mathrm{IU} / \mathrm{ml}$ & Very high viraemia \\
\hline
\end{tabular}

Table II: Hepatic iron grades (Rowe et al., 1977)

\begin{tabular}{ll}
\hline Grade of hepatic iron & Hepatic iron staining \\
\hline Grade 0 & No detectable hepatic iron \\
Grade I & Granules of iron resolved only at 400x magnification \\
Grade II & Granules of iron resolved only at 100x magnification \\
Grade III & Discrete iron granules resolved at 25x magnification \\
Grade IV & $\begin{array}{l}\text { Masses of iron visible to the naked eye or 10x } \\
\text { magnification }\end{array}$ \\
\hline
\end{tabular}

\section{Statistical Analysis:}

It was done by using mean $\mathrm{X}$, standard deviation (S.D.). Student's test (t) chi-square test (X2) $\mathrm{P}$ was considered significant if $\mathrm{P}<0.05$, highly significant if $\mathrm{P}<0.001$ and non significant if $\mathrm{P}>0.05$.

\section{Results}

The 40 studied cases' age ranged from 23-60 years. They were 33 male and 7 female. Out of 40 cases there were 14 patients farmers while 3 were medical personal and the rest were employee. On examination $34(85 \%)$ cases had hepatomegaly with no splenomegaly, ascitis nor other organo megally. As regards ultrasonographic findings $36(90 \%)$ had hepatomegaly with bright echopattern while all the rest had normal echopattern. No cases with coarse or heterogeneous echopattern were selected. There were $24(60 \%)$ patients with periportal fibrosis with no portal hypertension.

According to the results of hepatic iron staining in the Liver biopsies the patients were classified into grade 0 hepatic iron (20 cases) grade I hepatic iron (10 cases), grade II hepatic iron (8 cases) and grade III hepatic iron (2 cases) while there were no cases had grade IV hepatic iron. All the results will be illustrated and analyzed in the following tables (1-7) and figures (1-6). 
Table (1): Comparison between liver function tests before and after treatment in different groups of hepatic iron grades

\begin{tabular}{|c|c|c|c|c|c|c|c|c|c|c|}
\hline & \multicolumn{2}{|c|}{$\begin{array}{c}\text { Total Cases } \\
\mathbf{N}=\mathbf{4 0}\end{array}$} & \multicolumn{2}{|c|}{$\begin{array}{c}\mathbf{G} 0 \\
\mathbf{N}=\mathbf{2 0}\end{array}$} & \multicolumn{2}{|c|}{$\begin{array}{c}\text { G I } \\
\mathbf{N}=\mathbf{1 0}\end{array}$} & \multicolumn{2}{|c|}{$\begin{array}{c}\text { G II } \\
\mathbf{N}=8\end{array}$} & \multicolumn{2}{|c|}{$\begin{array}{l}\mathbf{G} \text { III } \\
\mathbf{N}=2\end{array}$} \\
\hline & Before & After & Before & After & Before & After & Before & After & Before & After \\
\hline $\begin{array}{c}\text { AST: } \\
\text { Mean } \\
\text { SD } \\
\text { Normal values } 38 \\
\text { IU/dl: }\end{array}$ & $\begin{array}{c}177.2 \\
\pm \\
124.3\end{array}$ & $\begin{array}{c}54.9 * \\
\pm \\
27.1\end{array}$ & $\begin{array}{c}139.8 \\
\pm \\
66.7\end{array}$ & $\begin{array}{c}39.03^{*} \\
\pm \\
14.02\end{array}$ & $\begin{array}{c}158.4 \\
\pm \\
62.2\end{array}$ & $\begin{array}{c}61.2 * \\
\pm \\
31.5\end{array}$ & $\begin{array}{c}268.3 \\
\pm \\
217\end{array}$ & $\begin{array}{c}78.6^{*} \\
\pm \\
21.3\end{array}$ & $\begin{array}{c}280 \\
\pm \\
185.2\end{array}$ & $\begin{array}{c}87.5 \\
\pm \\
24.7\end{array}$ \\
\hline $\begin{array}{c}\text { ALT: } \\
\text { Mean } \\
\\
\text { SD } \\
\text { Normal values } 41 \\
\text { IU/dl: } \\
\end{array}$ & $\begin{array}{c}195.1 \\
\pm \\
98.5\end{array}$ & $\begin{array}{c}56.2 * \\
\pm \\
31.2\end{array}$ & $\begin{array}{c}162.09 \\
\pm \\
79.6\end{array}$ & $\begin{array}{c}40.5^{*} \\
\pm \\
16.4\end{array}$ & $\begin{array}{c}191.3 \\
\pm \\
94.4\end{array}$ & $\begin{array}{c}61.6^{*} \\
\pm \\
26.9\end{array}$ & $\begin{array}{c}243 \\
\pm \\
109.8\end{array}$ & $\begin{array}{c}74.8^{*} \\
\pm \\
29.5\end{array}$ & $\begin{array}{c}354 \\
\pm \\
52.3\end{array}$ & $\begin{array}{c}111.5 \\
\pm \\
78.4\end{array}$ \\
\hline $\begin{array}{c}\text { S. Albumin level: } \\
\text { Mean } \\
\text { SD } \\
\text { Normal values } \\
3.5-5 \mathrm{mg} / \mathrm{dl}: \\
\end{array}$ & $\begin{array}{c}4.985 \\
\pm \\
5.205\end{array}$ & $\begin{array}{c}4.073 \\
\pm \\
0.376\end{array}$ & $\begin{array}{c}4.255 \\
\pm \\
0.341\end{array}$ & $\begin{array}{c}4.135 \\
\pm \\
0.392\end{array}$ & $\begin{array}{c}7.430 \\
\pm \\
10.400\end{array}$ & $\begin{array}{c}4.080 \\
\pm \\
0.418\end{array}$ & $\begin{array}{c}4.013 \\
\pm \\
0.295\end{array}$ & $\begin{array}{c}3.925 \\
\pm \\
0.287\end{array}$ & $\begin{array}{c}3.95 \\
\pm \\
7.071\end{array}$ & $\begin{array}{c}4.000 \\
\pm \\
0.424\end{array}$ \\
\hline $\begin{array}{c}\text { Total S. } \\
\text { Bilirubin: } \\
\text { Mean } \\
\text { SD } \\
\text { Normal values up } \\
\text { to } 1.1 \mathrm{mg} / \mathrm{dl}:\end{array}$ & $\begin{array}{c}0.97 \\
\pm \\
0.24\end{array}$ & $\begin{array}{c}1.01 \\
\pm \\
0.18\end{array}$ & $\begin{array}{c}0.83 \\
\pm \\
0.18\end{array}$ & $\begin{array}{c}0.92 \\
\pm \\
0.20\end{array}$ & $\begin{array}{c}1.11 \\
\pm \\
0.237\end{array}$ & $\begin{array}{c}1.08 \\
\pm \\
0.113\end{array}$ & $\begin{array}{c}1.075 \\
\pm \\
0.23\end{array}$ & $\begin{array}{c}1.137 \\
\pm \\
0.118\end{array}$ & $\begin{array}{c}1.3 \\
\pm \\
000\end{array}$ & $\begin{array}{c}1.100 \\
\pm \\
0.14\end{array}$ \\
\hline
\end{tabular}

* Significant difference $\mathrm{P}<0.05$

AST Aspartate transaminase

ALT Alanine transaminase 
Table (2): Comparison between blood picture before and after treatment in different groups of hepatic iron grades

\begin{tabular}{|c|c|c|c|c|c|c|c|c|c|c|}
\hline & \multicolumn{2}{|c|}{$\begin{array}{c}\text { Total Cases } \\
\qquad N=40\end{array}$} & \multicolumn{2}{|c|}{$\begin{array}{c}G 0 \\
N=20\end{array}$} & \multicolumn{2}{|c|}{$\begin{array}{c}G \text { I } \\
N=10\end{array}$} & \multicolumn{2}{|c|}{$\begin{array}{c}\text { G II } \\
N=8\end{array}$} & \multicolumn{2}{|c|}{$\begin{array}{c}\text { G III } \\
\mathbf{N}=2\end{array}$} \\
\hline & Before & After & Before & After & Before & After & Before & After & Before & After \\
\hline RBCs & 4.745 & $4.17^{*}$ & 4.83 & $4.27^{*}$ & 4.78 & $4.20^{*}$ & 4.43 & 4.01 & 4.90 & 3.70 \\
\hline & \pm & \pm & \pm & \pm & \pm & \pm & \pm & \pm & \pm & \pm \\
\hline Million $/ \mathrm{cm}^{3}$ & 4.986 & 3.58 & 4.41 & 3.34 & 5.11 & 3.7 & 5.28 & 3.39 & 8.48 & 0.00 \\
\hline Haemoglobin & 14.06 & $12.942^{*}$ & 13.92 & $12.99^{*}$ & 14.56 & $12.88^{*}$ & 13.77 & $12.9^{*}$ & 14.15 & 12.95 \\
\hline & \pm & \pm & \pm & \pm & \pm & \pm & \pm & \pm & \pm & \pm \\
\hline Gms/dl & 0.83 & 0.811 & 0.89 & 1.04 & 0.72 & 0.56 & 0.67 & 0.5 & 0.91 & 7.07 \\
\hline W.B Cells & 1.592 & $10.744^{*}$ & 18.596 & $11.009^{*}$ & 10.934 & $12.094^{*}$ & 9.192 & $10.081^{*}$ & 2.192 & 6.363 \\
\hline & \pm & \pm & \pm & \pm & \pm & \pm & \pm & \pm & \pm & \pm \\
\hline Thousands $/ \mathrm{cm}^{3}$ & 2.517 & 1.698 & 4.158 & 2.461 & 3.457 & 3.824 & 3.250 & 3.564 & 1.550 & 0.450 \\
\hline Platelet Count & 204.7 & $183.8^{*}$ & 216.7 & $188.9^{*}$ & 206.7 & $180.0^{*}$ & 188.2 & 177.1 & 186.0 & 183.0 \\
\hline & \pm & \pm & \pm & \pm & \pm & \pm & \pm & \pm & \pm & \pm \\
\hline Thousands $/ \mathrm{cm}^{3}$ & 48.08 & 23.8 & 55.15 & 27.64 & 45.8 & 15.03 & 45.3 & 25.09 & 70.7 & 2.828 \\
\hline
\end{tabular}

Table (3): Comparison between serum iron and serum ferritin levels before and after the treatment in the studied groups

\begin{tabular}{|c|c|c|c|c|c|c|c|c|c|c|}
\hline & \multicolumn{2}{|c|}{$\begin{array}{c}\text { Total Cases } \\
\mathrm{N}=40\end{array}$} & \multicolumn{2}{|c|}{$\begin{array}{c}\text { G } 0 \\
N=20\end{array}$} & \multicolumn{2}{|c|}{$\begin{array}{c}\text { G I } \\
N=10\end{array}$} & \multicolumn{2}{|c|}{$\begin{array}{c}\text { G II } \\
\mathbf{N}=8\end{array}$} & \multicolumn{2}{|c|}{$\begin{array}{l}\text { G III } \\
N=2\end{array}$} \\
\hline & Before & After & Before & After & Before & After & Before & After & Before & After \\
\hline \multirow{2}{*}{$\begin{array}{l}\text { S. iron } \\
\text { level }\end{array}$} & 147.9 & $134.5^{*}$ & 131.9 & 118.8 & 158.5 & 137.6 & 160.7 & 155.3 & 204 & 194 \\
\hline & $\begin{array}{c} \pm \\
45.01\end{array}$ & $\stackrel{ \pm}{44.9}$ & $\stackrel{ \pm}{ \pm 0.8}$ & $\stackrel{ \pm}{ \pm 0.9}$ & $\begin{array}{c} \pm \\
38.02\end{array}$ & $\stackrel{ \pm}{ \pm 6.5}$ & $\stackrel{ \pm}{ \pm 0.3}$ & $\stackrel{ \pm}{ \pm 3.4}$ & $\begin{array}{c} \pm \\
94.7\end{array}$ & $\stackrel{ \pm}{140}$ \\
\hline \multirow{2}{*}{$\begin{array}{l}\text { S. ferritin } \\
\text { level }\end{array}$} & 378.5 & $311.2^{* *}$ & 246 & $212^{*}$ & 409.2 & $302.1^{*}$ & 637.5 & $526^{*}$ & 514.5 & $486.5^{*}$ \\
\hline & $\begin{array}{c} \pm \\
262.9\end{array}$ & $\stackrel{ \pm}{ \pm} 206.3$ & $\begin{array}{c} \pm \\
173\end{array}$ & $\frac{ \pm}{123}$ & $\stackrel{ \pm}{ \pm}$ & $\begin{array}{c} \pm \\
102.7\end{array}$ & $\begin{array}{c} \pm \\
354\end{array}$ & $\begin{array}{c} \pm \\
302\end{array}$ & $\begin{array}{c} \pm \\
77\end{array}$ & $\begin{array}{c} \pm \\
71\end{array}$ \\
\hline $\begin{array}{l}* \\
* *\end{array}$ & $\begin{array}{l}\text { Significant } \\
\text { Highly si } \\
0.001\end{array}$ & $\begin{array}{l}p<0.05 \\
\text { gnificant }\end{array}$ & $\mathrm{p}$ & $\begin{array}{l}\text { erum irc } \\
\text { Male }=65 \\
\text { erum fe } \\
\text { Male 20- }\end{array}$ & $\begin{array}{l}\text { level no } \\
75 \mathrm{ug} / \mathrm{dl} \\
\text { itin level } \\
50 \mathrm{ng} / \mathrm{ml}\end{array}$ & $\begin{array}{l}\text { mal ran } \\
\text { and Fem } \\
\text { normal } \\
\text { and Fem }\end{array}$ & $\begin{array}{l}\text { le }=50-170 \\
\text { nge: } \\
\text { e } 20-120\end{array}$ & $\begin{array}{l}\mathrm{ug} / \mathrm{dl} \\
\mathrm{ng} / \mathrm{ml}\end{array}$ & & \\
\hline
\end{tabular}




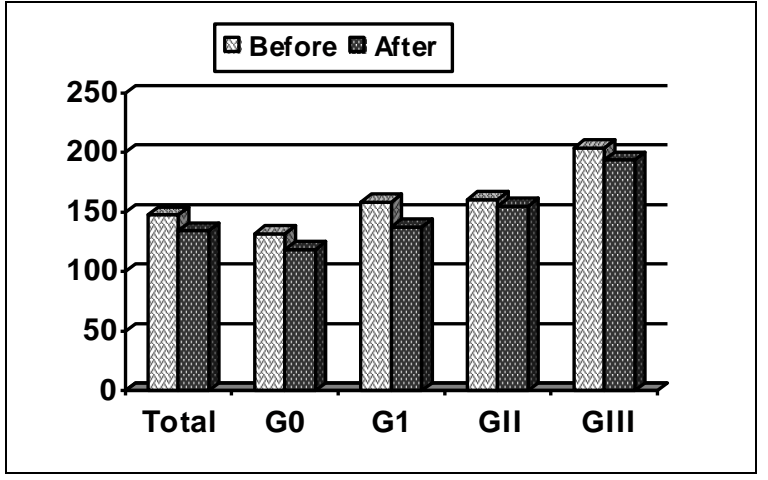

Fig. (1): Serum Iron Level in Different Studied Groups

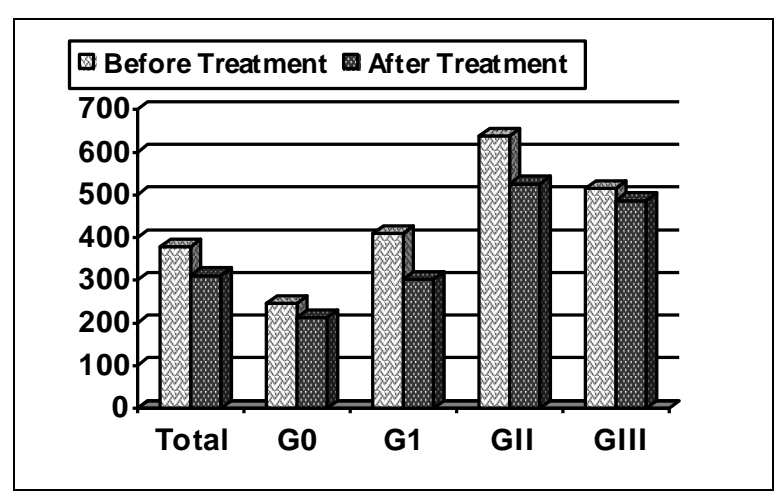

Fig. (2): Serum Ferritin Level in Different Studied Groups

Table (4): Relation between degree of HCV viraemia by quantitative PCR before and after treatment in different groups

\begin{tabular}{|c|c|c|c|c|c|c|c|c|c|c|}
\hline \multirow{2}{*}{$\begin{array}{l}\text { Grades of } \\
\text { Viraemia }\end{array}$} & \multicolumn{2}{|c|}{$\begin{array}{l}\text { Total Cases } \\
\mathbf{N}=40\end{array}$} & \multicolumn{2}{|l|}{$\begin{array}{l}\text { G 0 } \\
N=20\end{array}$} & \multicolumn{2}{|l|}{$\begin{array}{l}\text { G I } \\
\mathbf{N}=\mathbf{1 0}\end{array}$} & \multicolumn{2}{|l|}{$\begin{array}{l}\text { G II } \\
N=8\end{array}$} & \multicolumn{2}{|l|}{$\begin{array}{l}\text { G III } \\
\mathbf{N}=2\end{array}$} \\
\hline & Before & After & Before & After & Before & After & Before & After & Before & After \\
\hline Low & $\begin{array}{c}5 \\
(12.5 \%)\end{array}$ & $\begin{array}{c}14 \\
(35 \%)\end{array}$ & $\begin{array}{c}4 \\
(20 \%)\end{array}$ & $\begin{array}{c}9 \\
(45 \%)\end{array}$ & 0 & $\begin{array}{c}2 \\
(20 \%)\end{array}$ & $\begin{array}{c}1 \\
(12.5 \%)\end{array}$ & $\begin{array}{c}3 \\
(37.5 \%)\end{array}$ & 0 & 0 \\
\hline Moderate & $\begin{array}{c}22 \\
(55 \%)\end{array}$ & $\begin{array}{c}13 \\
(32.5 \%)\end{array}$ & $\begin{array}{c}13 \\
(65 \%)\end{array}$ & $\begin{array}{c}2 \\
(10 \%)\end{array}$ & $\begin{array}{c}6 \\
(60 \%)\end{array}$ & $\begin{array}{c}5 \\
(50 \%)\end{array}$ & $\begin{array}{c}3 \\
(37.5 \%)\end{array}$ & $\begin{array}{c}5 \\
(62.5 \%)\end{array}$ & 0 & $\begin{array}{c}1 \\
(50 \%)\end{array}$ \\
\hline High & $\begin{array}{c}11 \\
(27.5 \%)\end{array}$ & $\begin{array}{c}1 \\
(2.5 \%)\end{array}$ & $\begin{array}{c}3 \\
(15 \%)\end{array}$ & 0 & $\begin{array}{c}4 \\
(40 \%)\end{array}$ & 0 & $\begin{array}{c}2 \\
(25 \%)\end{array}$ & 0 & $\begin{array}{c}2 \\
(100 \%)\end{array}$ & $\begin{array}{c}1 \\
(50 \%)\end{array}$ \\
\hline V. High & $\begin{array}{c}2 \\
(5 \%) \\
\end{array}$ & 0 & 0 & 0 & 0 & 0 & $\begin{array}{c}2 \\
(25 \%)\end{array}$ & 0 & 0 & 0 \\
\hline
\end{tabular}

Table (5): Effect of the combined therapy on the absence of $\mathrm{HCV}$ viraemia and AST and ALT normalization in different studied groups

\begin{tabular}{|l|c|c|c|c|c|}
\hline & Total Cases & $\mathbf{G ~ 0}$ & G I & G II & G III \\
& $\mathbf{N = 4 0}$ & $\mathbf{N = 2 0}$ & $\mathbf{N = 1 0}$ & $\mathbf{N = 8}$ & $\mathbf{N}=\mathbf{2}$ \\
\hline Undetectable HCV & 12 & 9 & 3 & 0 & 0 \\
viraemia & $(30 \%)^{*}$ & $(45 \%) *$ & $(30 \%)$ & 0 & 0 \\
\hline Normalized AST & 18 & 15 & 2 & 0 & 0 \\
Normalized ALT & $(45 \%)$ & $(75 \%)$ & $(20 \%)$ & $1(12.5 \%)$ & 0 \\
& 17 & 13 & 4 & 0 & 0 \\
\hline
\end{tabular}




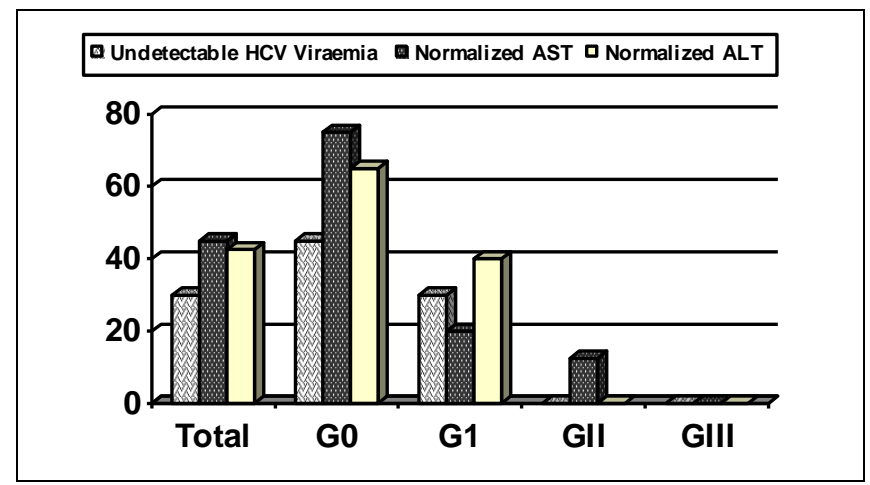

Fig. (3): Effect of the treatment on the absence of HCV viraemia and AST and ALT normalization in different studied groups

Table (6): The effect of the treatment on the liver biopsy changes in different studied groups

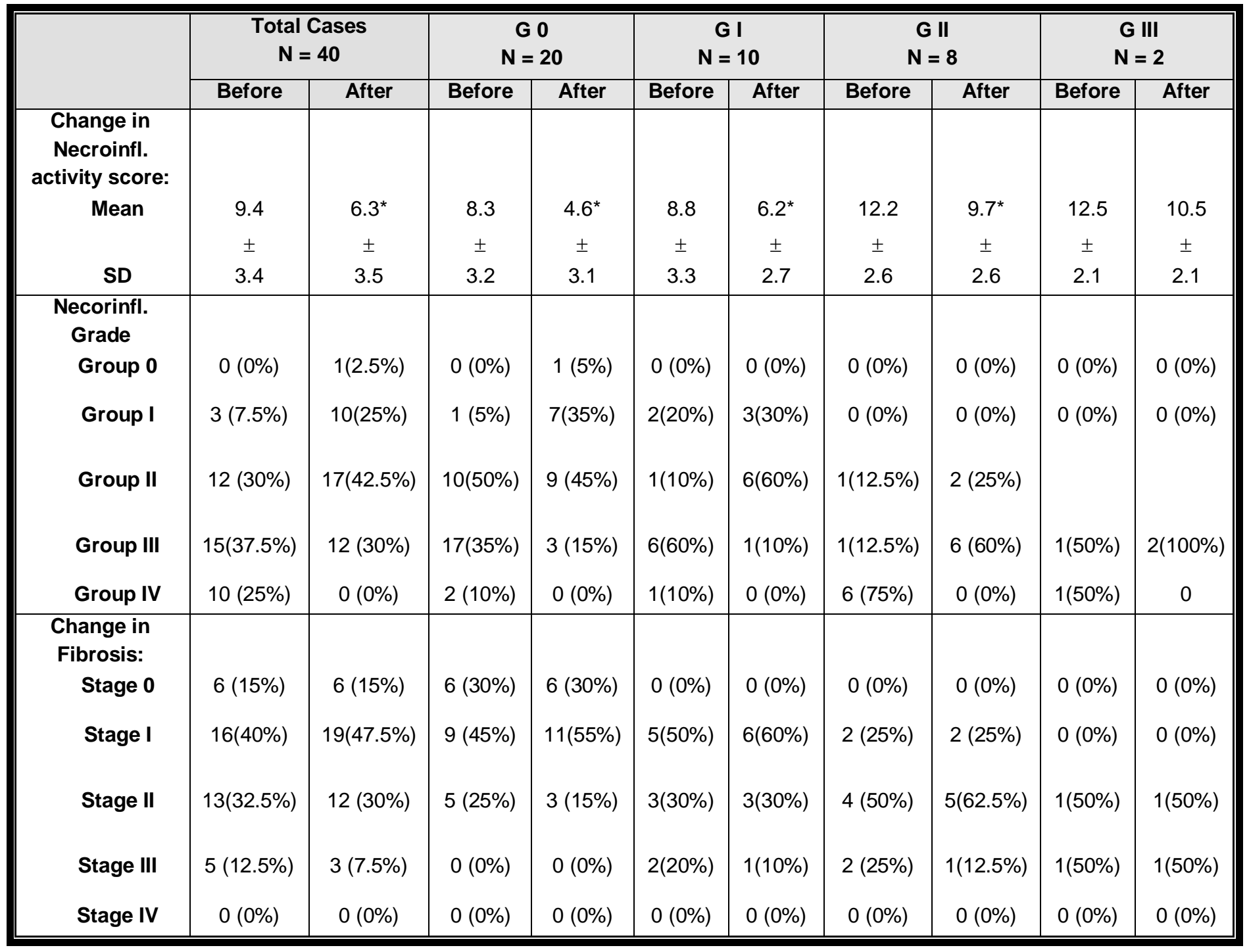


Table (7): Effect of combined therapy on the change of hepatic iron grading in total cases

\begin{tabular}{||l|l|l|l|l|l|l|l|l||}
\hline \multirow{2}{*}{$\begin{array}{l}\text { Total Cases } \\
\mathbf{n = 4 0}\end{array}$} & \multicolumn{2}{|l|}{ G 0 } & \multicolumn{2}{l|}{ G II } & \multicolumn{2}{l|}{ G III } \\
\cline { 2 - 8 } & Before & After & Before & After & Before & After & Before & After \\
\hline $\begin{array}{l}\text { Number of cases } \\
\%\end{array}$ & 20 & 21 & 10 & 11 & 8 & 7 & 2 & 1 \\
\hline
\end{tabular}

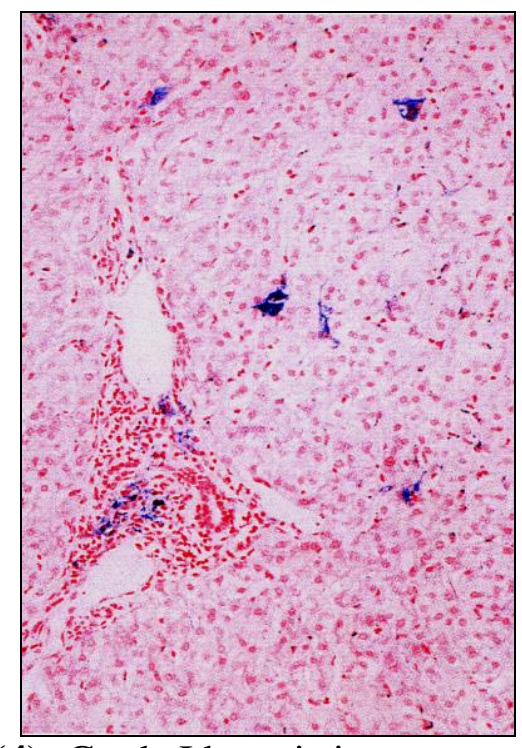

Figure (4): Grade I hepatic iron (Prussian blue stain for iron) x 400 magnification

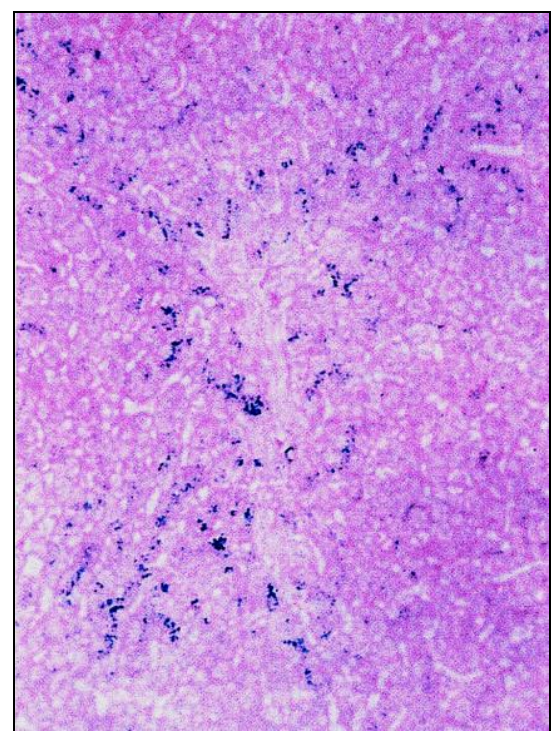

Figure (5): Grade II hepatic iron (Prussian blue stain for iron) x 100 magnification

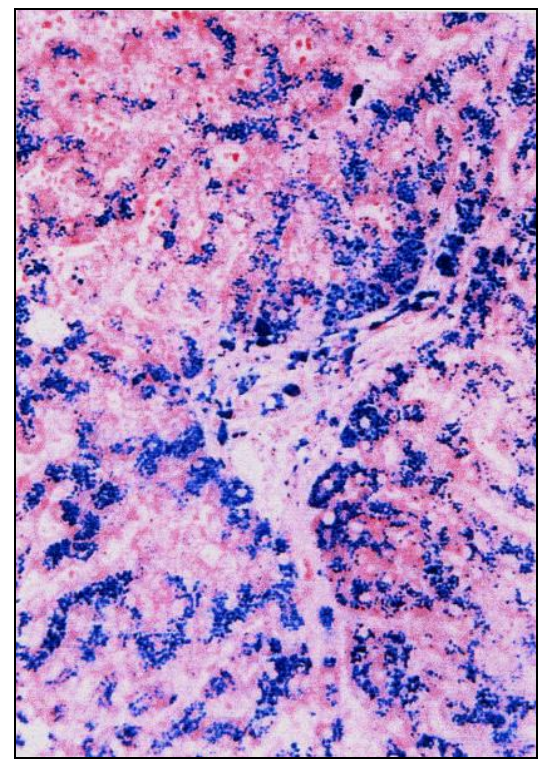

Figure (6): Grade III hepatic iron (Prussian blue stain for iron) x 25 magnification 


\section{Discussion}

The liver plays a crucial role in iron homeostasis. It is the major tissue repository of iron and is the site of synthesis of transferring, the plasma iron transporter, and ferritin, which is the major tissue iron storage protein. Therefore, processes that lead to chronic hepatic inflammation or necrosis could result in alterations in iron metabolism. Lysis of damaged hepatocytes might result in release of stored ferritin into the circulation leading to elevated ferritin levels. Chronic inflammation could alter normal regulation of transf erring receptor expression by hepato cytes, leading to increased iron uptake and resulting in increased hepatic iron concentration (Kris, 1997).

The panel of National Institutes of Health Consensus Development Conference on "Management of hepatitis C" set four standard indications for treatment of patients with chronic hepatitis C. Criteria include elevations in serum aminotransferase levels. Presence of HCV RNA in serum, chronic hepatictis on liver biopsy and no contraindications (National Institutes of Health Consensus, 1997).

In our study the selected cases had persistent elevations of ALT and AST nearly twice the normal for 6 months with positive HCV antibodies and diff erent degrees of HCV viraemia by PCR with confirmation of the diagnosis of chronic hepatitis by the liver biopsy. The response to therapy in chronic hep atitis $\mathrm{C}$ can be categorized biochem ically as shown by normal ALT and AST levels, virologically as shown by absence of detectable HCV RNA or histologically as shown by improve ments in liver biopsy results.

So the patients who did not show biochemical response to the therapy were more likely to have stainable hepatic iron than those who had a response (Barton et al., 1995)

In our study there was statistical significant decrease in the AST and ALT level before and after the therapy in total cases and in patients with hepatic iron grades 0, I and II. While there was no significant decrease in hepatic iron grades III. Similar results were obtained by Kageyama et al., (1998) who found that the non responders had a significantly higher hepatic iron grade compared with the responders.

Also we studied the degree of $\mathrm{HCV}$ viraemia by quantitative PCR before and after treatment we found that there were statistical significant decreease in its levels in total patients and in patients with hepatic iron grade $0, \mathrm{I}$ and II while there was no significant change in the degree of viraemia in patients with hepatic iron grade III.

Also there was a statistically significant difference as regards undetectable viraemia after therapy in total patients [12 cases (30\%)] and in patients with grade 0 [9 cases $(45 \%)]$ while there was no significant decrease in patients with grade I hepatic iron [3 cases (30\%)] while there is no cases found in grade II and III.

Also out of 9 patients have undetectable HCV viraemia after therapy in patients with grade 0 hepatic iron, we found that 6 patients with normal AST and ALT at the end of treatment (complete end of treatment response). While in patients with grade I hepatic iron no patients were found to have complete end of treatment response (undetectable $\mathrm{HCV}$ viraemia with normal transaminases).

These results were explained by poor response to combined therapy (biochemically and virologically) with 
the increase of hepatic iron grade. Olynyk et al. (1994) studied the hepatic iron concentration and the response to interferon therapy in patients with chronic hepatitis $\mathrm{C}$ and concluded that the hepatic iron concentration was higher in non-responders to interferon.

Also these results are similar to what obtained by Kageyama et al. (1998) who reported that there were poor responses to interferon therapy with the increased hepatic iron levels or stores. Olynyk and Clarke (1998) expl ained that by the effect of chronic iron overloads on Kupffer cell cytokine production. Kupffer cells exhibit redu ced proinflammatory cytokine produ ction compared with its actions in controls. Thus iron loading could impair immune clearance mechanisms via impaired macrophage function.

Another explanation that iron may also substrate for viral replication and patients with iron overload may have enhanced viral replication in the sitting of chronic hepatitis C (Litwin and Colderwood 1993). On the other hand, Boucher et al. (1997) and Sievert et al. (2002) conflict that with their reports about the long term response to interferon is unrelated to hepatic iron in chronic hepatitis $\mathrm{C}$ patients.

As regards the serum iron level before and after therapy in our study we found that there was a statistically sign ificant decrease in their levels in total patients while there was no statistical significant change with different hepatic iron grades. Although it was elevated in the elevated grades of hepatic iron grades. This was agreed with that reported by Walker (2000) who stated that the hyperferremia with hepatic iron overload is associated with suppressed functions of the complement system.

As regards serum ferritin level it was elevated in 26 patients out of 40 $(65 \%)$ before therapy while it was elevated in 23 (57.3\%) after therapy. Out of 20 patients with elevated hepatic iron (grades I, II, III) of them (90\%)have also elevated serum ferritin before therapy and become 15 (15\%) after therapy. So we found that there was statistical significant difference between serum ferritin level before and after therapy in total cases and in patients with hepatic iron grade 0 and grade I while there was no significant difference in patients with hepatic iron grade II and III. Fabris et al. (2001) reported that serum iron and ferritin are believed to be elevated in patients with $\mathrm{HCV}$ infection in connection to the presence of hepatic inflammation. Also they stated that serum iron reflect the degree of current hepatic inflammation and necrosis, whereas the extent of progressive deposition of hepatic iron in sites of fibrosis is best reflected by serum ferritin level. While Piperno et al., (1992) noted that serum ferritin in patients with chronic hepatitis $\mathrm{C}$ was higher in those with normal histology but lower in those with fibrosis or cirrhosis.

It is of our interest to note that in contrast to previous studies on hepatic iron, serum iron and serum ferritin in our study there was elevated hepatic iron with increased serum ferritin (90\% of patients with increased hepatic iron). Still there was no parallel increase in serum iron $(35 \%$ of patients with increased hepatic iron). Further studies are still needed in order to elucidate this issue.

As regards histopathological response to treatment in different hepatic iron grades. In our study the necroinflammatory score was improved significantly in total cases and in grade 0 , I and II hepatic iron versus to what found in fibrosis staging. This was in agreement to the results done by Poynard et al. (1998) and Rigamonti et 
al. (2002) who explained those results by the hepatic iron which could play a role in the activation of hepatic stellate cells and in the progression of fibrosis. Also Beinker et al. (1996) concluded that the increased iron may have been raised from damaged hepatocytes while Boucher et al. (1997) identified relation between hepatic iron concentration and inflammatory activity as the iron load was higher in those patients with greatest degree of histological activity. Increased iron stores in those patients may be a result of the degree of inflammatory activity.

Although in this study out of 20 Patients have hepatic iron staining (grade I, II, III) before therapy, only 4 cases improved their hepatic iron staining after therapy but still with no significant value.

Kakizaki et al. (2000) concluded that the hepatic iron decreased signify cantly following treatment with interf eron therapy even in patients without successful treatment suggesting that an antiinflammatory effect of interferon is likely to contribute to iron depletion.

Fiel et al. (2000) and Van et al. (2002) reported an increased hepatic iron deposition through the course of ribavirin therapy due to associated hemolytic deposits of iron in hepato cytes. This increased deposition of hepatic iron does not seem to affect the biochemical of histological response to ribavirin therapy but may have implic ations for hepatocyte susceptibility to future injury.

In this study similar effect of therapy on hepatic iron was not obser ved in chronic HCV patients without successful treatment. This discrepancy may possibly be explained by adding of ribavirin to interferon, which may cou nteract the significant decrease in hepatic iron as in interferon therapy alone.
We concluded that the hepatic iron overload in chronic HCV patients is an important factor guarding against biochemical response (normalization of AST and ALT). Virological response (undetectable quantitative HCV RNA) and improvement of histopathological activity index after combined therapy, also it has to be distinguished from the states of elevated serum iron and serum ferritin, as there may be hepatic iron overload with normal serum iron and/or ferritin and also the reverse is possible. More studies in this direction are needed to clarify the exact relation between them.

As there was not yet detectable clear relation that combined therapy affect the degree of hepatic iron but repeated venesections must be done before combined therapy for those who have elevated hepatic iron.

\section{References}

1. Barton A, Banmer B, Gable E (1995). Distribution of iron in the liver predicts the response of chronic hepatitis $\mathrm{C}$ infection to INF therapy. Am. J. Clinical Pathol. 103: 419-42.

2. Beinker NS, Voigt M, Arendse $M$ (1996). Threshold effect of liver iron content on hepatic inflammation and fibrosis in hepatitis B and C J. Hepatol; 25: 633-8.

3. Boucher $\mathbf{E}$, Bouienne A, Adams $\mathbf{P}$ (1997). Liver iron concentration and distribution in chronic hepatitis $\mathrm{C}$ before and after interferon treatment. Gut; 41: 115-20.

4. Chayama K, Suzuki F, Tusbota A (2001). Evaluation of quantitative measurements of hepatitis $\mathrm{C}$ virus RNA to predict sustained response to interferon by genotype. J. Viro. Methods; 95 (1-2): 33-45.

5. Fabris $\mathbf{C}$, Toniutto $\mathbf{P}$. and Scott $\mathbf{C}$ (2001). Serum iron indices as a measure iron deposits in chronic HCV. Clin. Chim. Acta; 304 (1-2): 49-55. 
6. Fiel M, Schiano T, Guido M (2000). Increased hepatic iron deposition resulting from treatment of chronic hepatitis $\mathrm{C}$ with ribavirin. Am. J. Clin. Pathol.; 113 (1): 35-9.

7. Kageyama F, Kobayashi Y, Kawasak T (2000). Successful interferon therapy reverses enhanced hepatic iron accumulation in chronic hepatitis C; Am. J. Gastroenterol. Apr., 95 (4): 1041-50.

8. Kageyama F, Kobayashi Y, Murohisa G (1998). Failure to respond to interferon alpha $2 b$ therapy is associated with increased hepatic iron levels in patients with chronic hepatitis C. Bio. Trace. Elem. Res.; 64 (1-3): 185-96.

9. Kakizaki S, Takagi, H, Ichikawa T (2000). Histological changes after interferon therapy in chronic hepatitis $\mathrm{C}$ in view of iron deposition in the liver. Biol. Trace. Elem. Res. 73 (2): 151-62.

10. Kaserer $\mathbf{K}$, Fiedler $\mathbf{R}$, Steind $\mathbf{L}$ (1998). Liver biopsy is useful predictor of response to interferon therapy in chronic hepatitis C Histopathological; May; 32 (5): 454-61.

11. Knodell R, Ishak K, Black W (1981). Formulation and application of a numerical scoring system for assessing histological activity in asymptomatic chronic active hepatitis: Hepatology; 1; 431-5.

12. Kris M (1997). The Role of iron in chronic viral hepatitis. Marcel Dekker INC., New York.

13. Litwin C, and Colderwood S (1993). Role of iron in regulation of virulence genes. Clin. Microbiol. Rev.; 6:137138.

14. National Institutes of Health Consensus (1997). Management of Hepatitis C, Hepatology; 26 (suppl): 25-105.

15. Olynyk J and Clarke L (1998). Functional heterogenecity of Kupffer cells in iron overload, Hepatology; 28:1115 A.

16. Olynyk J, Neill R, Britton R, Bacon B (1994). Determination of hepatic iron concentration in fresh and paraffin embedded tissue Gastroenterology; 106: 674-7.

17. Piperno A, Farigion $\mathbf{S}$ and Aiba $A$ (1992). Liver damage in Italian patients with hereditary haemochromatosis is highly influenced by hepatitis $\mathrm{C}$ virus infection. J. Hepatol., 16: 364-8.

18. Poynard T, Mc Hutchison J, Davis G et al. (1998). Impact of Interferon alfa $2 b$ and ribavirin on the liver fibrosis progression in patients with chronic hepatitis C Hepatology; 28:497A.

19. Rigamonti C, Andorno S, Meduli S (2002). Iron hepatic stellate cells and fibrosis in chronic hepatitis C. Eur. J. Clin. Invest; 32:28.

20. Rowe J, Wands J, Mezey E (1977). Familial haemochromatosis. Medicine 56:197-211.

21. Schalm S, Hansen B, Chemello $L$ (1997). Ribavirin enhances the efficacy but not the adverse effects of interferon in chronic hepatitis C. J. Hepatology; 26:961-6.

22. Sievert W, Pianko S, Warner S (2002). Hepatic iron overload does not prevent a sustained virological response to interferon alpha therapy. Am. J. Gastroenterol; 97 (4): 982-7.

23. Van V, Verdinvel H, Colle I (2002). Non-transferring bound iron in untreated and ribavirin treated chronic hepatitis C patients. Alimentary Pharmacology and therapy 16 (8): 1555-62.

24. Walker E (2000). Effect of iron overload on the immune system. Ann. Clin. Lab. Sci.; 30 (4): 354-65.

25. WHO (1999). WHO weekly Epidemiological Record: hepatitis C Global Prevalence; 49 (10): 425. 


\section{نسبة الحديد والفريتين بالام ومحتوى الحديد الكبدى وقيمتهم التنبوئة}

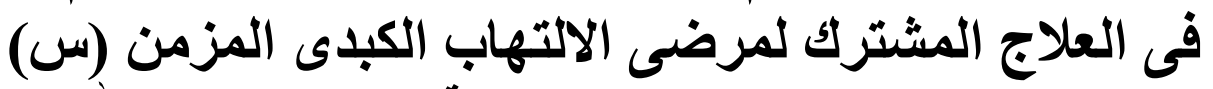

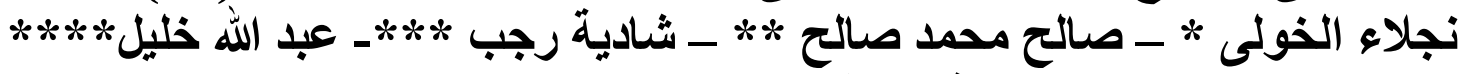

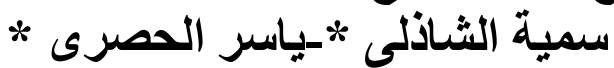

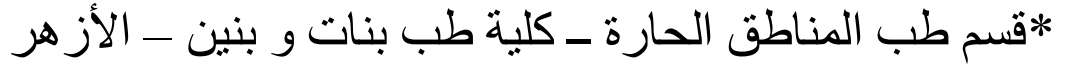

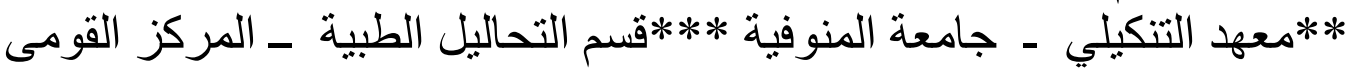

$$
\text { لالبحوث }
$$

|قشم الباثولوجي - جامعة القاهرة

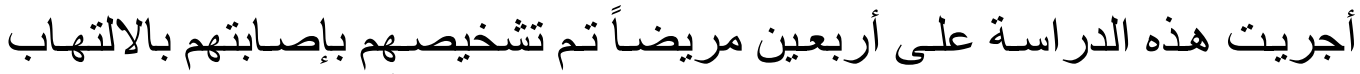

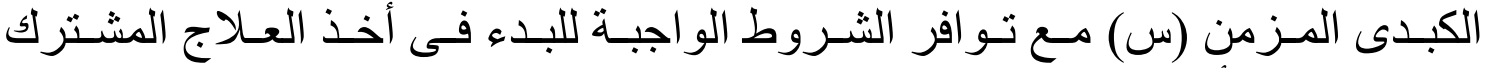

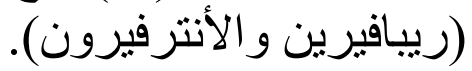

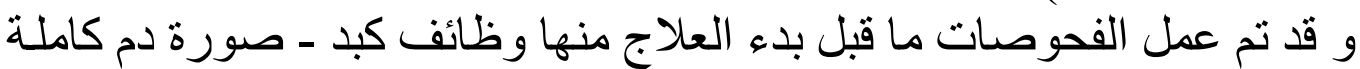

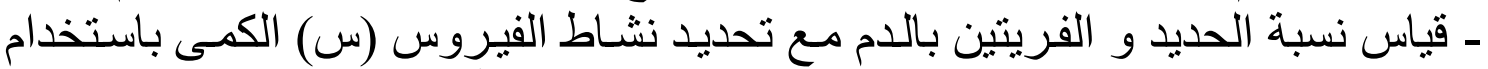

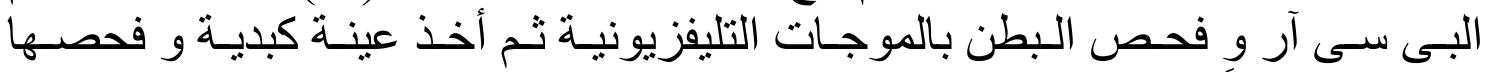

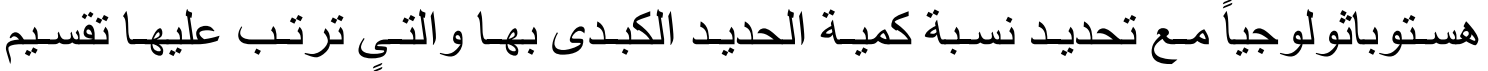

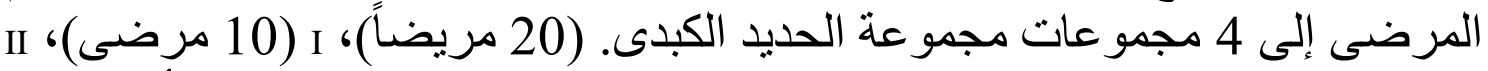

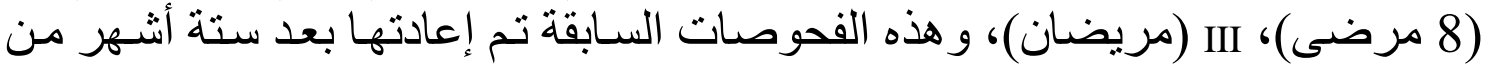

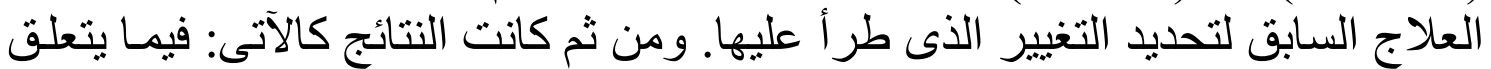

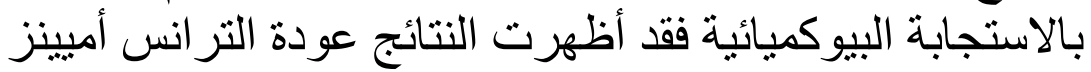
(ALT, AST)

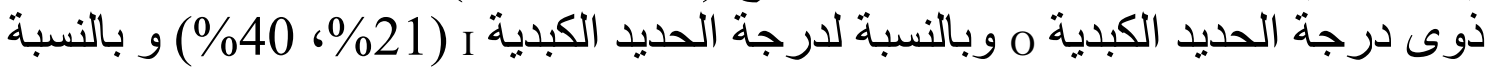

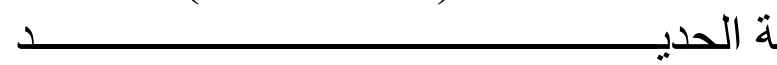

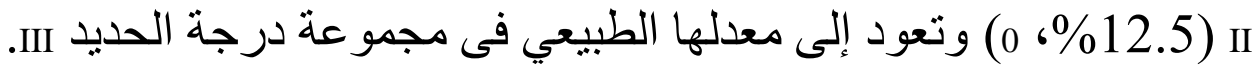

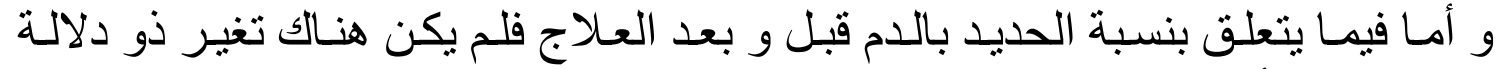
إحصائية فى أى من درجات الحئ الحيد الكبدية المختلفة.

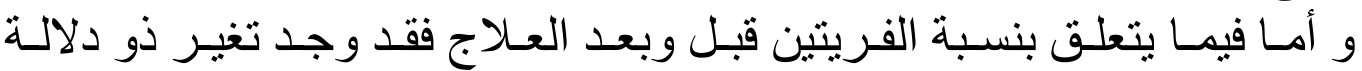

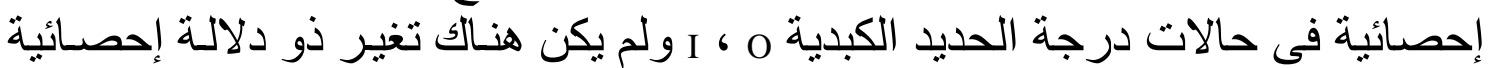

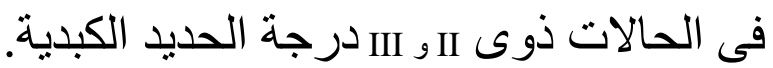

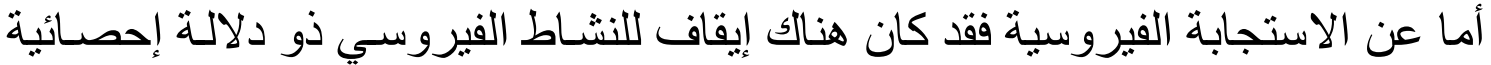

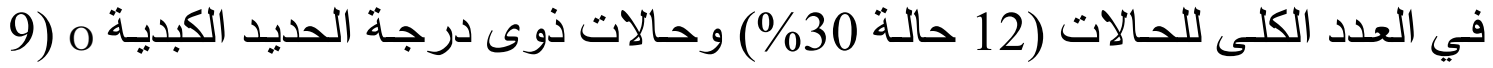

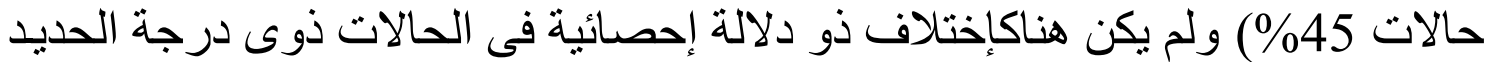

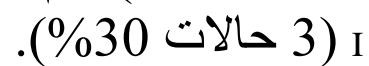

و أيضاً وجد أن هناك دلالة إحصائية فى درجة التحسن بالنسبة للنشاط الالتهابى بخلايا

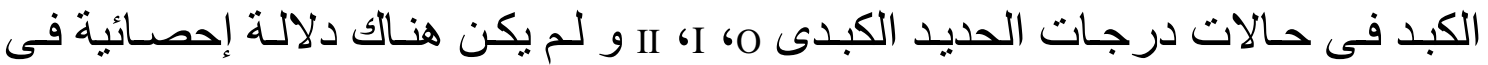




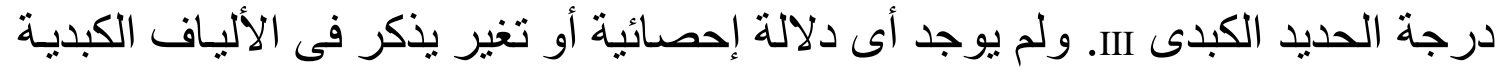

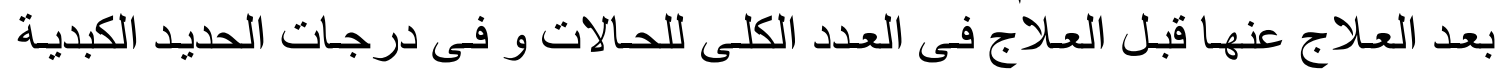
المختلفة. وعن تأثثر العلاج المشترك على التى التغير الطارئ فى درجة الحديد فقد وجد أندا

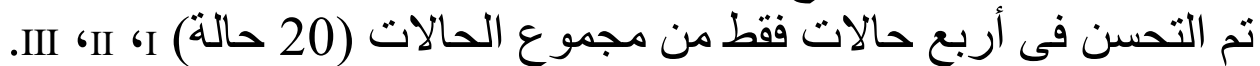

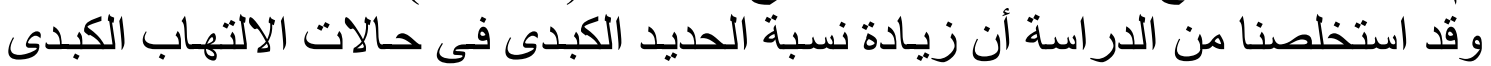

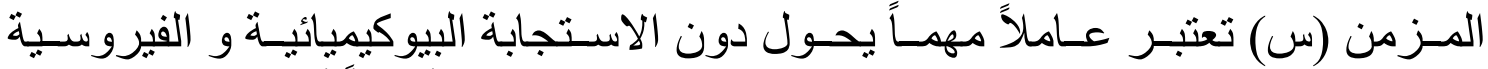

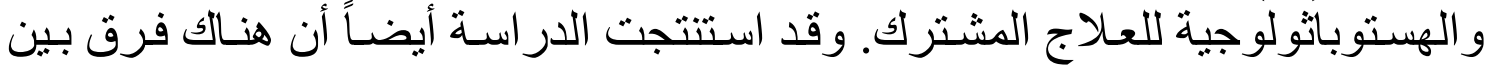

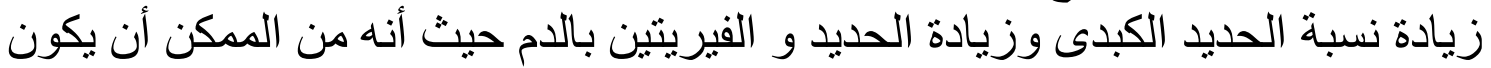

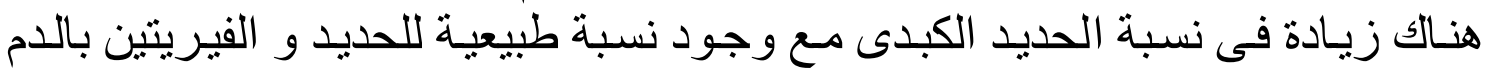

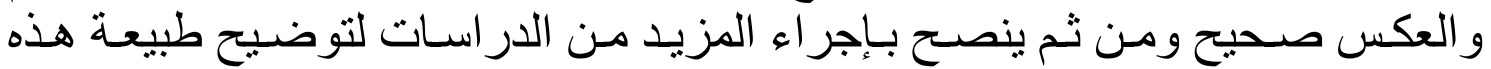
العلاقة فى مرضى الالتهاب الكبدى المزمن (س). 